DOI: http://dx.doi.org/10.24093/awejtls/vol2no3.3

\title{
The Impact of John Locke's Tabula Rasa and Kant's faculty of intuition on the Poetry of Wordsworth, Coleridge and Keats: Implications and Applications
}

\author{
Walid Ali Zaiter \\ Department of Languages and Translation \\ Taibah University, Saudi Arabia
}

\begin{abstract}
:
Both Immanuel Kant (1724- 1804) and John Locke (1632-1704) have transformed the thought and ideology of almost all walks of life ( culture, literature, science, politics, and philosophy) in the eighteenth, nineteenth centuries and beyond. This paper explores the impact of their philosophy on the Romantics' poetry. Thus, the paper argues that the Romantics Wordsworth, Coleridge and Keats had refuted John Locke's Tabula Rasa and adapted Kant's faculty of intuition to create their poetry. Adapting Kant's faculty of intuition in the Critique of Pure Reason (1781), a new theory of knowledge, the Romantics denounced Locke's tabula rasa in Locke's An Essay Concerning Human Understanding (1690). Unlike Locke, Kant treats the mind as active organ. For this reason the Romantics took up Kant's theory and left behind Locke's tabula rasa. This paper (a study) aims to find where Locke's tabula rasa and Kant's intuition converge and diverge. The study provides a historical and theoretical background of these philosophies and their impact on the Romantics under study. Thus, it paves the way for further investigation for those who are concerned to tackle any angle of the study.

Key words: Imagination, Locke's An Essay concerning Human Understanding and Tabula Rasa, Kant's faculty of Intuition, Wordsworth's Prelude, Coleridge's "Dejection: An Ode" Keats's" Ode to Psyche"

Cite as: Zaiter, W. A. (2018). The Impact of John Locke's Tabula Rasa and Kant's faculty of intuition on the Poetry of Wordsworth, Coleridge and Keats: Implications and Applications. Arab World English Journal for Translation \& Literary Studies, 2 (3).

DOI: http://dx.doi.org/10.24093/awejtls/vol2no3.3
\end{abstract}

